\title{
Seismic retrofitting of mid-rise reinforced concrete framed structures
}

\author{
Y. E. Ibrahim \\ Engineering Management Department, Prince Sultan University, KSA \\ On leave: Structural Engineering Department, \\ Zagazig University, Egypt
}

\begin{abstract}
Seismic codes for buildings are being revised worldwide after the occurrence of recent earthquakes that has led to the realization that these codes are not sufficiently definitive in terms of design requirements as well as structural performance. Accordingly, it may be the case that buildings that were designed according to old seismic codes need to be rechecked to provide information on the predicted performance of existing structures. If performance enhancement under potential earthquakes is deemed necessary for a particular structure, retrofitting may be required. This can be achieved by increasing the lateral stiffness of the structure by increasing the columns' dimensions and reinforcement, adding steel braces or through using energy dissipating devices. In this research, finite element analysis is used via the software SeismoStruct to study the effectiveness of retrofitting existing multistory reinforced concrete framed structures in improving structural seismic performance. To this end, three models were analyzed: 4-story, 8-story and 12-story reinforced concrete framed structures, designed according to Saudi Building Code (2007) for vertical loads and seismic forces for 0.2 -second and 1.0-second response spectral accelerations of $0.21 \mathrm{~g}$ and $0.061 \mathrm{~g}$, respectively. Two retrofitting techniques are considered to upgrade the structures to withstand seismic forces for 0.2 -second and 1.0-second response spectral accelerations of $0.66 \mathrm{~g}$ and $0.23 \mathrm{~g}$, respectively, which represent the highest spectral accelerations in KSA based on the current code. The study included nonlinear static pushover analysis and incremental dynamic analysis using records of twelve artificial and historic earthquakes. The results showed that retrofitting techniques using column jacketing and steel braces enhanced the
\end{abstract}


structural response of all models. The efficacy of using steel braces is better than for column jacketing in almost all analyzed cases.

Keywords: retrofitting, incremental dynamic analysis, nonlinear static pushover analysis, reinforced concrete frames, steel braces.

\section{Introduction}

Subsequent to recent major earthquakes and their devastating damage to structures, building codes and method of seismic design are being reviewed by building authorities around the world. One of the expected outcomes of code reviews is the necessity to strengthen and retrofit existing structures to meet new resistance demands. There are many well-known seismic retrofitting techniques for structures, which can be categorized into two main groups [1]:

- Conventional methods, based on improving the strength, stiffness and ductility of the structure, and

- Innovative response modification methods, which aim to reduce the effect of seismic forces on structures.

Conventional methods include techniques such as increasing the lateral stiffness of structural systems by: increasing dimensions of reinforced concrete columns, adding reinforced concrete infill walls to the structural system and adding braces to existing reinforced concrete frames [2, 3]. Fortunately, these methods can be readily designed and applied using conventional construction techniques. However, it should be noted that excessive increase in lateral stiffness may induce larger earthquake forces and lower ductility, which affects the structural seismic performance. On the other hand, these retrofitting measures may be associated with heavy demolition and construction work [4].

Sarno and Elnashai [5] assessed the seismic performance of 9-story steel moment-resisting perimeter frames retrofitted with different bracing systems including special concentrically braces, buckling-restrained braces and megabraces. The retrofitting did enhance the performance in some cases with the maximum story drifts in retrofitted frames being $70 \%$ lower than with the original frames.

Sarno and Manfredi [6] used buckling restrained braces placed along the perimeter frames of a two-story building to enhance the seismic performance of the structure, which was designed for gravity loads only. Nonlinear static pushover and dynamic time history analyses using seven real earthquake records were carried out using SeismoStruct [7] for both the as-built and retrofitted structure.

Another retrofitting method was proposed by Durucan and Dicleli [1]. They used a system of a rectangular steel housing frame with chevron braces and a yielding shear link connected between the braces and the frame. They examined both the proposed system and another conventional retrofitting system of squat infill shear panels for retrofitting an existing school and an office building.

Wei-Wen Chen et al. [8] studied the out-of-plane seismic behavior of reinforced concrete frames infilled with brick walls. They concluded that 
retrofitting enhanced the peak lateral strength and residual strength in tested specimens. Ozel and Guneyisi [9] investigated the seismic reliability of a midrise reinforced concrete building retrofitted using eccentric steel braces through fragility analysis. A six story mid-rise reinforced concrete building designed according to 1975 version of the Turkish Seismic Code was selected. They examined the effectiveness of using $\mathrm{D}, \mathrm{K}$, and $\mathrm{V}$ types of eccentric steel braces in retrofitting the building.

Innovative techniques include installing passive control devices such as dampers to help dissipating energy during earthquakes, which enhances structural response [10]. When used for seismic retrofitting, innovative techniques usually do not require heavy demolition or construction work. However, they are generally costly to be used for retrofitting ordinary buildings [11].

In this research, finite element analysis is utilized, using SeismoStruct, to study the effectiveness of seismic retrofitting of existing multistory reinforced concrete framed structures. Three structural models are considered: 4-story, 8story and 12-story reinforced concrete framed structures designed according to the current Saudi Building Code for a certain seismic intensity. Two conventional retrofitting techniques are selected to enhance the structural seismic capacity to withstand higher seismic forces corresponding to the highest spectral accelerations in KSA according to current code. Nonlinear static pushover analysis and incremental dynamic analysis using records of twelve artificial and historic earthquakes are carried out in the analysis; a comparison between the results of both retrofitting techniques is made.

\section{Structural models}

The structures considered in this research represent typical mid-rise reinforced concrete residential framed structures in KSA. Three structural models are selected: 4-story, 8-story and 12-story moment-resisting frames. The structures are three-bay frames with first story height of $5 \mathrm{~m}$, while the height of the rest of the floors is $3 \mathrm{~m}$ each. The bay width is $5 \mathrm{~m}$ and the frames are $4 \mathrm{~m}$ apart. The compressive strength of the concrete used is $300 \mathrm{Kg} / \mathrm{cm}^{2}$, while the yielding stress of the reinforcing steel is $3600 \mathrm{Kg} / \mathrm{cm}^{2}$. The structural models are shown in fig. 1 . The soil class is assumed $\mathrm{D}$, indicating stiff soil with shear wave velocity, $V_{S}$, ranging from 180 to $370 \mathrm{~m} / \mathrm{s}$. The structures are classified as low hazard buildings, with importance factor $I=1$. According to the modal analysis, the natural time period is $0.66,0.88$ and 1.06 seconds for the 4-story, 8-story and 12 story structural models, respectively.

In the current research, the structural models were first designed by the author according to the Saudi Building Code [12] for vertical loads and seismic forces for 0.2 -second and 1.0-second response spectral accelerations of $0.21 \mathrm{~g}$ and $0.061 \mathrm{~g}$, respectively. The seismic design equivalent lateral forces at each floor were calculated from the relationship:

$$
F_{X}=C_{V X} V
$$


where $V$ is the total base shear and $C_{V X}$ is the vertical distribution factor calculated from:

$$
C_{V X}=\frac{W_{x}^{*} h_{x}^{k}}{\sum W_{i}^{*} h_{i}^{k}}
$$

$W_{i}$ or $W_{x}$ is the portion of the total gravity load of the structure $(W)$ located or assigned to level $i$ or $x$, respectively.

$h_{i}$ or $h_{x}$ is the height (m) from the base to level $i$ or $x$, respectively.

$k$ is an exponent related to the structure period. For structures having a period of $0.5 \mathrm{sec}$ or less, $k=1.0$ while for structures having a period between 0.5 and 2.5 seconds, $k$ is calculated by linear interpolation between 1.0 and 2.0 according the specific period value. For ordinary moment-resisting frames, the seismic response modification coefficient is taken to be 4 . Details of the designed sections of the beams and columns of the three original structures are summarized in table 1 .

Table 1: $\quad$ Section details (Case 1).

\begin{tabular}{|c|c|c|c|}
\hline \multirow{2}{*}{ Model } & \multirow{2}{*}{ Beams } & \multicolumn{2}{|c|}{ Columns } \\
\cline { 3 - 4 } & & Ext. & Int. \\
\hline 4-story & B1 & C1 & C1 \\
\hline 8-story & B1 & C1 & C2 \\
\hline 12-story & $\begin{array}{l}\text { B2 for 1 } 1^{\text {st }} \text { floor } \\
\text { B1 for the rest }\end{array}$ & C1 & C3 \\
\hline
\end{tabular}

\section{Retrofitting techniques}

As mentioned earlier, two retrofitting techniques were used. The first technique is to jacket the columns and increase their reinforcing bars in order to withstand larger seismic forces through 0.2 -second and 1.0-second response spectral accelerations of $0.66 \mathrm{~g}$ and $0.23 \mathrm{~g}$, respectively. It should be noted, it is likely that these spectral accelerations may eventually be specified by the revised building codes after poor performance during a recent earthquake or when there is a need to enhance the structural performance under future earthquakes. The structural models were redesigned considering the new seismic forces and the details of the revised cross sections of the columns are tabulated in table 2 (case 2).

Table 2: $\quad$ Section details (Case 2).

\begin{tabular}{|c|c|c|}
\hline \multirow{2}{*}{} & \multicolumn{2}{|c|}{ Columns } \\
\cline { 2 - 3 } & Ext. & Int. \\
\hline 4-story & C3 & C4 \\
\hline 8-story & C3 & C4 \\
\hline 12-story & C3 & C5 \\
\hline
\end{tabular}

The second retrofit technique is to add concentric steel braces to the existing reinforced concrete frames to withstand the same seismic forces as in case 2 (0.2- 
second and 1.0-second response spectral accelerations of $0.66 \mathrm{~g}$ and $0.23 \mathrm{~g}$, respectively). In this scenario, the braces are added at each floor of the structural models in the middle bay of the frames, as shown in fig. 2. The cross sections of the beams and columns of the original models (i.e. case of no retrofit) were not changed, presuming the added braces will carry the increase in the seismic forces. The structural models with the added braces are shown in fig. 2. The brace models and their cross sections are tabulated in tables 3 and 4 (Case 3). The cross sections and reinforcement of the beams and columns of all models are listed in table 5 and table 6 , respectively.

Table 3: $\quad$ Braces models (Case 3).

\begin{tabular}{|c|l|}
\hline $\begin{array}{l}\text { Structural } \\
\text { model }\end{array}$ & Brace model \\
\hline 4-story & $\begin{array}{l}\text { Brace } 2 \text { for } 1^{\text {st }} \text { floor } \\
\text { Brace } 1 \text { for the rest }\end{array}$ \\
\hline 8-story & $\begin{array}{l}\text { Brace } 3 \text { for } 1^{\text {st }} \text { floor } \\
\text { Brace } 1 \text { for the rest }\end{array}$ \\
\hline 12-story & $\begin{array}{l}\text { Brace } 3 \text { for } 1^{\text {st }} \text { floor } \\
\text { Brace } 2 \text { for } 2^{\text {nd }} \text { to } 5^{\text {th }} \text { floor } \\
\text { Brace } 1 \text { for the rest }\end{array}$ \\
\hline
\end{tabular}

Table 4: Braces sections.

\begin{tabular}{|l|l|l|l|}
\hline $\begin{array}{l}\text { Beam } \\
\text { Model }\end{array}$ & $\begin{array}{l}\text { Dim. } \\
\text { cm x cm }\end{array}$ & $\begin{array}{l}\text { Tension } \\
\text { reinf. }\end{array}$ & $\begin{array}{l}\text { Comp. } \\
\text { reinf. }\end{array}$ \\
\hline B1 & $25 \times 50$ & $4 \phi 16$ & $2 \phi 12$ \\
\hline B2 & $25 \times 60$ & $6 \phi 16$ & $2 \phi 14$ \\
\hline
\end{tabular}

Table 5: Beam sections.

\begin{tabular}{|l|l|l|}
\hline $\begin{array}{l}\text { Brace } \\
\text { Model }\end{array}$ & Section & $\begin{array}{l}\text { Area } \\
(\mathrm{cm} 2)\end{array}$ \\
\hline Brace 1 & W6x12 & 22.90 \\
\hline Brace 2 & W8x18 & 33.94 \\
\hline Brace 3 & W12x30 & 56.71 \\
\hline
\end{tabular}

Table 6: Columns sections.

\begin{tabular}{|c|l|l|}
\hline $\begin{array}{l}\text { Column } \\
\text { model }\end{array}$ & $\begin{array}{l}\text { Dim. } \\
\mathrm{cm} \mathrm{x} \mathrm{cm}\end{array}$ & Reinf. \\
\hline $\mathrm{C} 1$ & $30 \times 30$ & $6 \phi 16$ \\
\hline $\mathrm{C} 2$ & $30 \times 40$ & $8 \phi 16$ \\
\hline $\mathrm{C} 3$ & $30 \times 50$ & $10 \phi 16$ \\
\hline $\mathrm{C} 4$ & $30 \times 60$ & $18 \phi 16$ \\
\hline $\mathrm{C} 5$ & $30 \times 70$ & $18 \phi 16$ \\
\hline
\end{tabular}



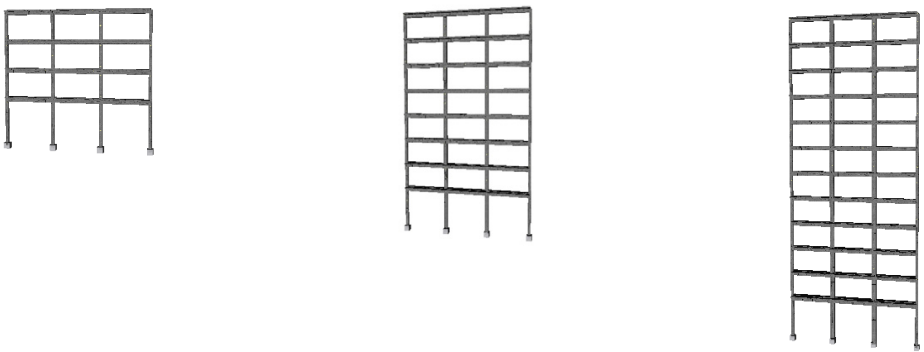

a) 4-story

b) 8-story

c) 12-story

Figure 1: Models of original structures (no retrofit) (Case 1).
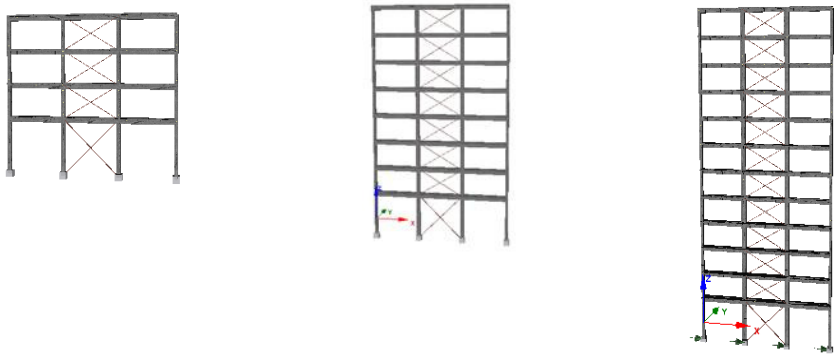
a) 4-story
b) 8-story
c) 12-story

Figure 2: $\quad$ Models of retrofitted structures using steel braces (Case 3).

\section{Nonlinear static pushover analysis}

Nonlinear static pushover analysis is frequently used to estimate the horizontal capacity of structures. In this analysis, horizontal static forces were applied at each floor and were incrementally increased until a target displacement was achieved or until instability of the structure is reached. The static force, $F_{X}$, applied at floor $\mathrm{X}$ is calculated from the relationship:

$$
F_{X}=\frac{W_{x} * h_{x}}{\sum W_{i}^{*} h_{i}}
$$

The software SeismoStruct was used to perform the nonlinear static pushover analysis for the 4-story, 8-story and 12-story structural models in the three cases: original, retrofitted using column jacketing and retrofitted using steel braces. In the analysis, the concrete was modeled using the uniaxial constant confinement concrete model initially presented by Madas [13]. In this model, the confinement effects provided by the lateral transverse reinforcement are included through the model introduced earlier by Mander et al. [14]; it assumes constant confining pressure throughout the entire stress-strain range. The reinforcing bars were simulated using a uniaxial bilinear stress-strain model with kinematic strain hardening. The elastic range remains constant throughout the various loading 
stages, and the kinematic hardening rule for the yield surface is assumed as a linear function of the increment of plastic strain. The results of the pushover analysis are shown in fig 3.

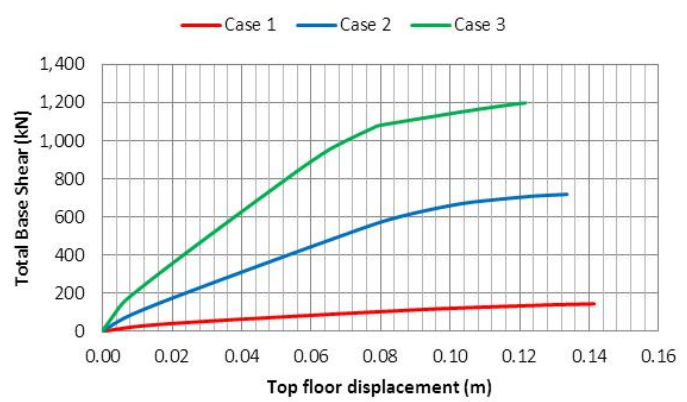

a) 4-story

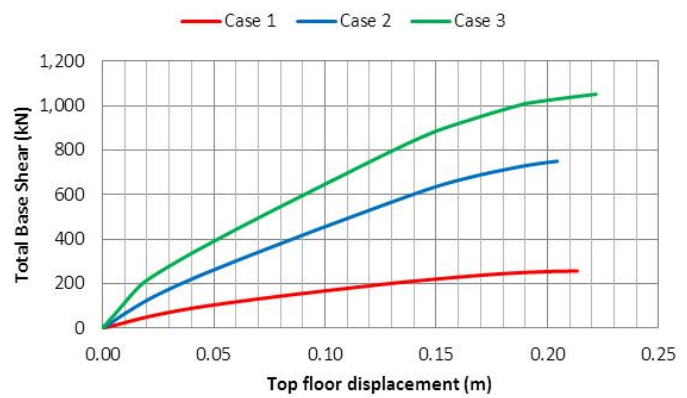

b) 8-story

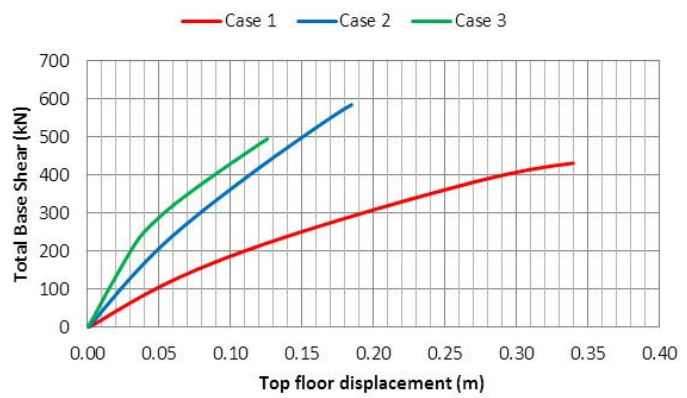

c) 12-story

Figure 3: Results of nonlinear static pushover analysis.

Inspection of the results in fig. 3 reveals that the horizontal capacity of all structural models increased by both retrofitting techniques. The enhancement in the structural capacity is significant in the 4-story case compared with the 8-story and 12-story models for both techniques. Retrofitting using steel braces results in better enhancement compared with column jacketing, especially for the 4-story 
and 8 -story models. For 12 -story model both retrofitting techniques have very similar effect.

\section{Incremental dynamic analysis}

In this analysis, the structural models were subjected to twelve ground motions, described in the next section, using SeismoStruct. Under each ground motion, nonlinear time history analyses were conducted while scaling the peak ground acceleration, PGA, of the used ground motion incrementally every $0.10 \mathrm{~g}$, until structural instability was reached or when the PGA equals a maximum value of $1.0 \mathrm{~g}$, whichever occurs first. The analysis produces the relationship between the maximum interstory drift ratio and the corresponding PGA, which creates the incremental dynamic analysis (IDA) curves for a certain structure under the specified ground motion. The IDA curves of the 4-story and 8-story are presented in fig. 4.

\subsection{Ground motions}

An appropriate set of ground motions is required to perform the incremental dynamic analysis. For mid-rise buildings, ten to twelve ground motions are normally required in order to provide accurate estimation of the seismic demand [15]. These ground motions can be selected either from real records of earthquakes or from artificially generated records. Real records are generally more realistic, since they include all ground motions characteristics such as amplitude, frequency, duration, energy content, number of cycles and phase [16]. No ground motions were recorded in the past in KSA. Accordingly, in this analysis, twelve records of hypothetical ground motions were selected to perform the nonlinear time history analysis of the chosen structures: one record is artificial and the rest were real records of historical earthquakes. The characteristics of these ground motions are presented in table 7 . The IDA curves

Table 7: Characteristics of ground motions used.

\begin{tabular}{|c|c|c|c|c|}
\hline No. & $\begin{array}{c}\text { Ground } \\
\text { motion }\end{array}$ & Location & $\begin{array}{c}\text { PGA } \\
(\mathrm{g})\end{array}$ & Year \\
\hline 1 & Artificial & generated by SeismoStruct & 0.436 & N/A \\
\hline 2 & ChiChi & Taiwan & 0.808 & 1999 \\
\hline 3 & Loma Prieta & Corralitos station, USA & 0.799 & 1989 \\
\hline 4 & Loma Prieta, & Emeryville station, USA & 0.250 & 1989 \\
\hline 5 & Friuli & Italy & 0.479 & 1976 \\
\hline 6 & Hollister & City Hall station, USA & 0.120 & 1974 \\
\hline 7 & Kocaeli & Sakaria station, Turkey & 0.628 & 1999 \\
\hline 8 & Kern County & Taft Lincoln School Tunnel, CA, USA & 0.179 & 1952 \\
\hline 9 & San Fernando & 8244 Orion Blvd, CA, USA & 0.134 & 1971 \\
\hline 10 & Imp. Valley & EL Centro, USA & 0.349 & 1940 \\
\hline 11 & Northridge & Arleta and Nordhoff Fire Station, USA & 0.344 & 1994 \\
\hline 12 & Parkfield & Cholame, Shandon, CA, USA & 0.275 & 1966 \\
\hline
\end{tabular}




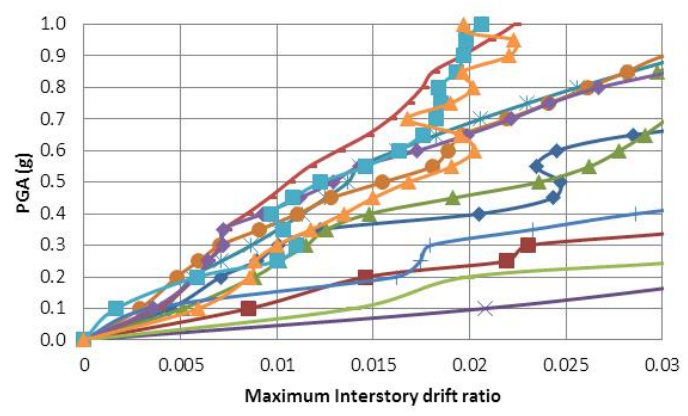

a) Case 1

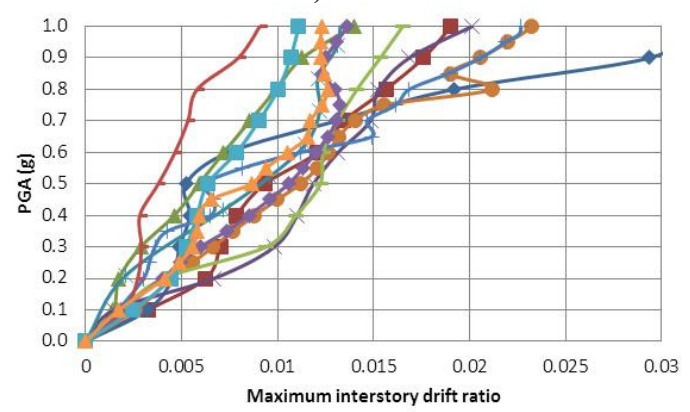

b) Case 2

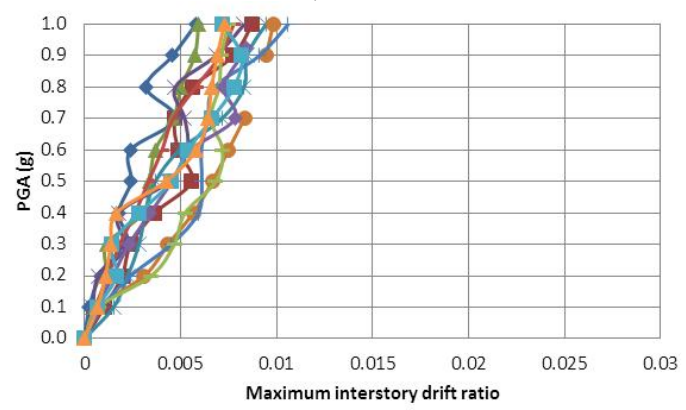

c) Case 3

Figure 4: IDA curves for the 4-story structural model.

developed for the three structural models considering the three cases of original structures and the retrofitted ones using the two different techniques are shown in figs 4, 5 and 6. The average IDA curves for the different cases of the three structural models under all used earthquakes are shown in fig. 7.

According to the results obtained, there is an enhancement in the structural response using both retrofitting techniques for 4-story, 8-story and 12-story structural models. The steel braces retrofit (Case 3) has better effect on the structural performance than column jacketing (Case 2). For earthquakes with 
PGA of $0.2 \mathrm{~g}$, which is considered relatively a weak ground motion, the interstory drift ratios obtained for the original structures (Case 1) are higher than 0.005 for all applied ground motions (i.e. 12) for the 4-story building, and 5 out of the 12 examined ground motions for the 8 -story building and 8 out of the 12 examined ground motions. However, in Case 2 , the 0.005 value of interstory drift ratio was exceeded for the same intensity of ground motions under 2, 3 and 4 ground motions out of the 12 for the 4-story, 8-story and 12-story structural models, respectively.

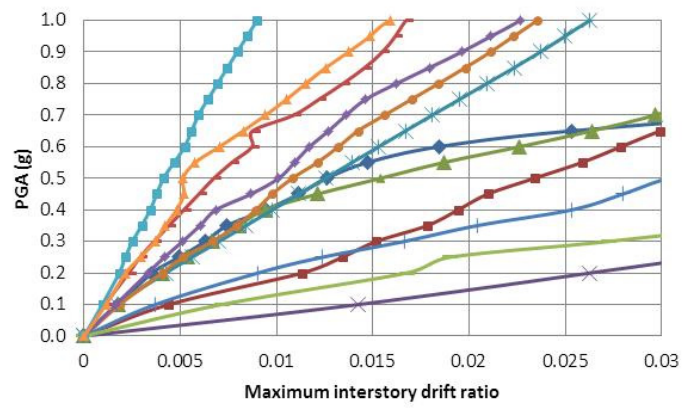

a) Case 1

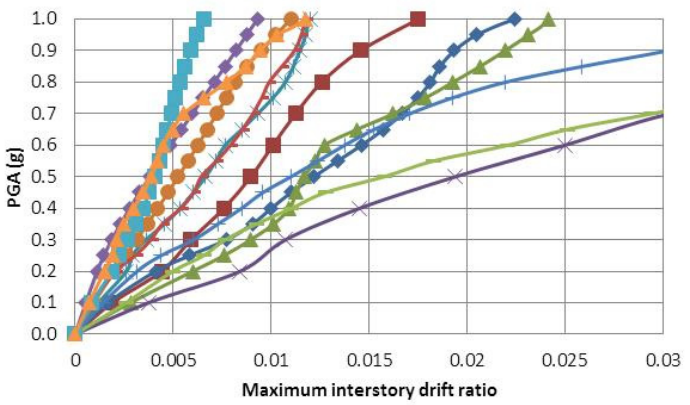

b) Case 2

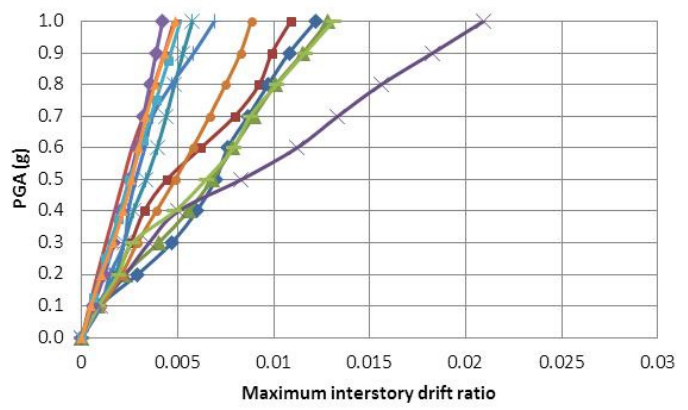

c) Case 3

Figure 5: IDA curves for the 8-story structural model. 


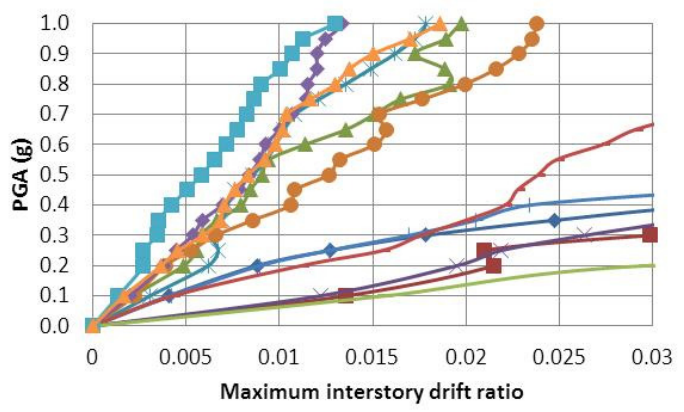

a) Case 1

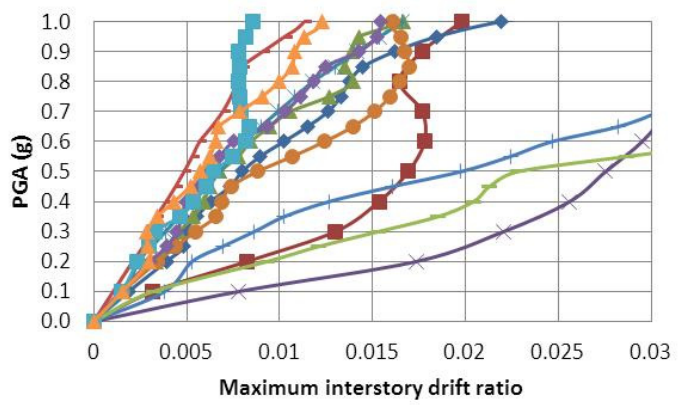

b) Case 2

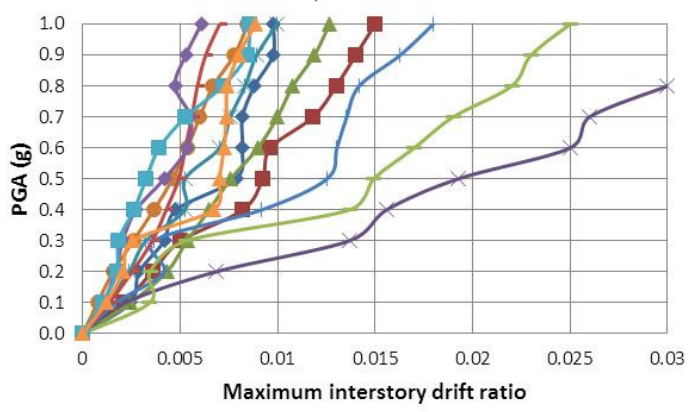

c) Case 3

Figure 6: IDA curves for the 12-story structural model.

The improvement in the seismic response in Case 2 is significant in that the 0.005 interstory drift ratio value was exceeded only under one ground motion for the 12-story structural model. It should be noted, however, that even with an interstory drift ratio of 0.005 , the structure will remain operational by definition (i.e., continuous service with negligible structural and non-structural damage [17]).

For relatively stronger earthquakes with a PGA of $0.4 \mathrm{~g}$, the structural models in Case 1 have interstory drift ratios higher than 0.005 under most of the applied ground motions for the 3 structural models. Specifically, this drift ratio was 
44 Earthquake Resistant Engineering Structures X

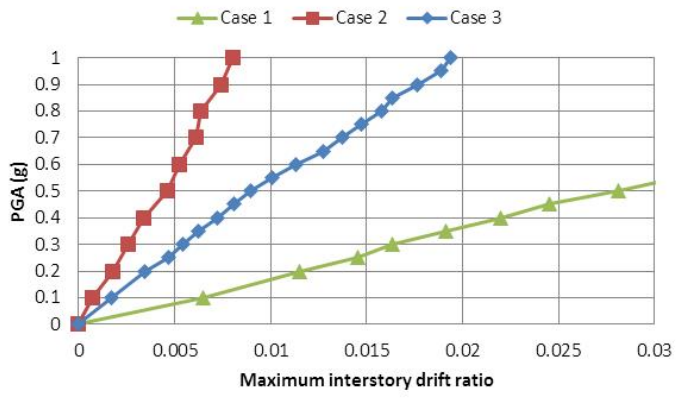

a) 4-story

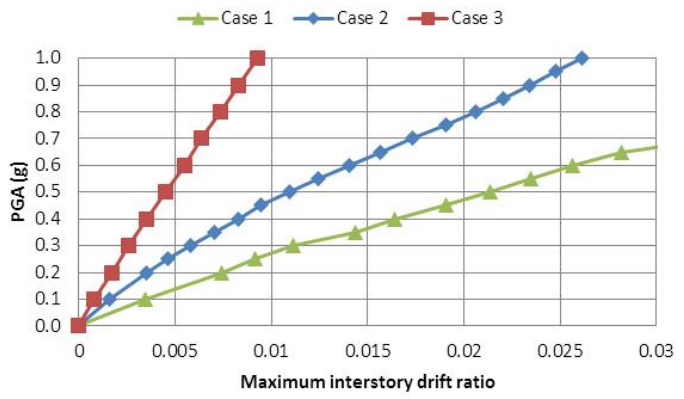

b) 8-story

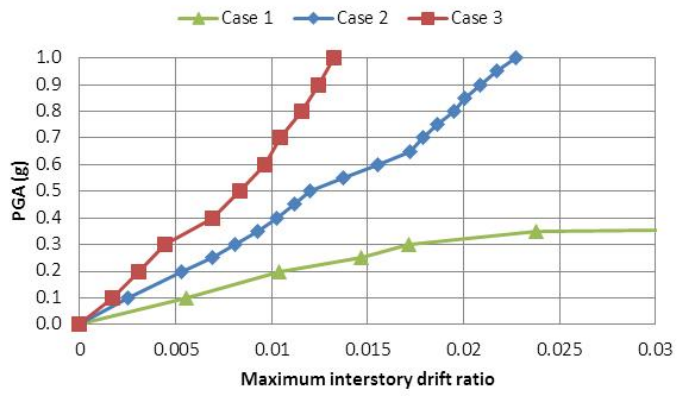

c) 12-story

Figure 7: Average IDA curves for structural models under all earthquakes.

exceeded in 12, 10 and 11 ground motions for 4-story, 8-story and 12-story structural models, respectively. However, the retrofit of Case 2 reduced the number of ground motions leading to exceedance of the 0.005 drift ratio to 10,8 and 9 ground motions for the 4-story, 8-story and 12-story structural models, respectively. The performance with the retrofit of Case 3 was more effective, with the exceedance occurring under only 3, 4 and 7 ground motions (out of 12) for the 4-story, 8-story and 12-story structural models, respectively. According to these results, retrofitting using steel braces has better effect on the enhancement 
in the case of 4-story structural model than for the 8-story and 12-story structural models. Accordingly, mega braces (extended over more than one floor) may be a better choice for retrofitting higher structures.

\section{Conclusions}

Three structural models have been selected to assess the effectiveness of two retrofitting techniques (using column jacketing and steel braces) in improving the structural seismic performance of existing structures. These models are for typical 4-story, 8-story and 12-story reinforced concrete residential structures built in accordance to KSA building codes. The analysis was conducted using nonlinear static pushover analysis and incremental dynamic analysis, utilizing twelve, artificial ground motions by SeismoStruct. According to the results obtained, the following conclusions are drawn:

1. Retrofitting techniques using column jacketing and steel braces enhanced the structural response of all models. The efficacy of steel braces is better than for column jacketing in almost all analyzed cases.

2. Low rise structures can be more efficiently retrofitted if compared with higher structures in case same retrofitting technique is utilized.

3. Although incremental dynamic analysis gives better illustration of the effectiveness of retrofitting techniques, especially when a large number of ground motions are considered, nonlinear static pushover analysis can predict the enhancement reasonably well. In the present paper, good agreement of the results was obtained from both methods.

Future analysis will aim at developing fragility curves for the structural models in the different cases considered. Several performance levels will be considered, including operational, immediate occupancy, life safety and near collapse to quantify the damage under potential earthquakes. This will provide more insight into the effectiveness of these retrofitting techniques. Retrofitting using different types of steel braces, such as K, D and V types, will be included in the future research. Also, mega braces will be investigated as an alternative configuration to the techniques used in this paper.

\section{Acknowledgement}

The research is funded by Prince Sultan University under the grant titled "Seismic Retrofitting of Mid-rise Reinforced Concrete Framed Structures in KSA" in the academic year 2014/2015.

\section{References}

[1] Durucan, C. \& Dicleli, M, Analytical study on seismic retrofitting of reinforced concrete buildings using steel braces with shear link. Engineering Structures, 32(10), pp. 2995-3010, 2010.

[2] Endo T., Okifuji, A., Sugano, S., Ayashi, T., Shimizu, T. \& Takahara, K, Practices of seismic retrofit of existing concrete structures in Japan. 
Proceedings of the $8^{\text {th }}$ world conference on earthquake engineering, vol. 1, pp. 469-476, 1984.

[3] Ghobarah, A., El-Attar, M. \& Aly, N. M, Evaluation of retrofit strategies for reinforced concrete columns: a case study. Engineering Structures, 22(5), pp. 490-501, 2000.

[4] Kelly, J. M, A seismic Base isolation: review and bibliography. Soil Dynamics and Earthquake Engineering, 5(4), pp. 202-216, 1986.

[5] Sarno, L. D. \& Elnashai, A. S, Bracing systems for seismic retrofitting of steel frames. Journal of Constructional Steel Research, 65(2), pp. 452465, 2009.

[6] Sarno, L. D. \& Manfredi, G, Seismic retrofitting with buckling restrained braces: Application to an existing non-ductile RC framed building. Soil Dynamics and Earthquake Engineering, 30(11), pp. 1279-1297, 2010.

[7] SeismoStruct Ver. 7.0.0, SeismoSoft, Earthquake Engineering Software Solutions, Italy. (www.seismosoft.com), 2014.

[8] Chen, W., Yeh, Y. K., Hwang, S. J., Lu, C. H. \& Chen, C. C, Out-of-plane seismic behavior and CFRP retrofitting of RC frames infilled with brick walls. Engineering Structures, 34, pp. 213-224, 2012.

[9] Ozel, A. E. \& Guneyisi, E. M, Effects of eccentric steel bracing systems on seismic fragility curves of mid-rise R/C buildings: A case study. Structural Safety, 33(1), pp. 82-95, 2011.

[10] Soong, T. T. \& Spencer Jr, B. F, Supplemental energy dissipation: stateof-the-art and state-of-the-practice. Engineering Structures, 24(3), pp. 243-259, 2002.

[11] Ahmad, S., Ghani, F. \& Adil, R, Seismic friction base isolation performance using demolished waste in masonry housing. Construction Building Materials, 23(1), pp. 146-152, 2009.

[12] Saudi Building Code, SBC 301: Loads and Forces Requirements. Riyadh, KSA. Saudi Building Code National Committee, 2007.

[13] Madas, P, Advanced modelling of composite frames subjected to earthquake loading. PhD Thesis, London, UK: Imperial College, University of London, 1993.

[14] Mander, J. B., Priestley, M. J. N. \& Park, R, Theoretical stress-strain model for confined concrete. Journal of Structural Engineering, 114(8), pp. 1804-1826, 1988.

[15] Shome, N. \& Cornell, C. A, Probabilistic seismic demand analysis of nonlinear structures, PhD dissertation, Stanford, Stanford University, 1999.

[16] Rota, M., Penna, A. \& Magnes, G, A methodology for deriving analytical fragility curves for masonry buildings based on stochastic nonlinear analyses. Engineering Structures, 32(5), pp. 1312-1323, 2010.

[17] Structural Engineers Association of California, SEAOC, Vision 2000, Performance based seismic engineering of buildings. Sacramento, CA: Vision 2000 Committee, 1995. 